\title{
Perlindungan Anak Perspektif Hukum Islam dan Perundang-undangan
}

\author{
Nurlaila Harun \\ UIN Syarif Hidayatullah Jakarta, Indonesia \\ E-mail: lailaharun04@gmail.com
}

\begin{abstract}
Children are children, and not little adults. Thus, the treatment of children whether involved in criminal acts or those experiencing social problems must be addressed for the welfare of children. The need for children adoption within Indonesian Islamic community will also be increasingly important for those who need it, in order to obtain legal certainty in which can be obtained by a court decision including the decision of the Religious Court. The marriage law and religious justice law have regulated in detail about child care and guardianship which are compiled in a compilation of Islamic law. The Law on Religious Courts explicitly states that the Religious Courts are a court for Muslims regarding cases or matters that are in its authorities. Muslims in this case are not only adults but also children. Unfortunately, the issue of children protection is not referred explicitly in the authorities of the Religious Courts. However, to serve and to fulfill the legal needs of Muslims regarding to child care, the Religious Courts, at the request of someone who adopts a child based on Islamic law, may issue a decision on adoption in terms of the child concerned as a proof of completion of the will must be regulated in the Compilation of Islamic law of Religious Courts. Consequently, the rights and obligations of parents who have adopted children with Islamic law have special characteristics that are different from the rights and obligations of parents who have adopted children without Islamic law.
\end{abstract}

Keywords: children protection; law; regulation

Abstrak. Anak-anak adalah anak-anak, dan bukan orang dewasa kecil. Dengan demikian, perlakuan terhadap anak-anak apakah terlibat dalam tindakan kriminal atau mereka yang mengalami masalah sosial harus ditangani untuk kesejahteraan anak-anak. Kebutuhan adopsi anak dalam komunitas Islam Indonesia juga akan semakin penting bagi mereka yang membutuhkannya, untuk mendapatkan kepastian hukum yang dapat diperoleh melalui keputusan pengadilan termasuk keputusan Pengadilan Agama. Hukum perkawinan dan hukum keadilan agama telah mengatur secara rinci tentang pengasuhan anak dan perwalian yang disusun dalam kompilasi hukum Islam. Undang-Undang tentang Pengadilan Agama secara eksplisit menyatakan bahwa Pengadilan Agama adalah pengadilan bagi umat Islam tentang kasus atau hal-hal yang ada dalam otoritasnya. Muslim dalam hal ini tidak hanya orang dewasa tetapi juga anakanak. Sayangnya, masalah perlindungan anak tidak dirujuk secara eksplisit dalam otoritas Pengadilan Agama. Namun, untuk melayani dan memenuhi kebutuhan hukum umat Islam terkait perawatan anak, Pengadilan Agama, atas permintaan seseorang yang mengadopsi anak berdasarkan hukum Islam, dapat mengeluarkan keputusan tentang adopsi dalam hal anak yang bersangkutan sebagai bukti penyelesaian kehendak harus diatur dalam Kompilasi hukum Islam Pengadilan Agama. Akibatnya, hak dan kewajiban orang tua yang mengadopsi anak dengan hukum Islam memiliki karakteristik khusus yang berbeda dengan hak dan kewajiban orangtua yang mengadopsi anak tanpa hukum Islam.

Kata Kunci: Perlindungan anak; hokum; undang-undang

Permalink/DOI: https://doi.org/10.15408/harkat.v15i1.10398 


\section{Pendahuluan}

Di negara berkembang termasuk Indonesia kita menyaksikan bagitu banyak hak-hak anak "diperkosa”. Anak kehilangan kesempatan untuk bermain. Banyak diantara mereka terpaksa bekerja dan bekerja tanpa mengenal waktu (contoh kasus kematian Angelina yang disiksa ibu angkatnya). Dan bekerja baik sebagian pemulung, penjual koran, buruh dan melakukan berbagai pekerjaan kasar lainnya. Tak jarang anak-anak pun menjadi objek pemerasan pihak tertentu. Di bawah ancaman mereka disuruh melakukan perbuatan yang tak semestinya mereka lakukan selain itu, anak-anak pun tak jarang menjadi objek kekerasan seksual.

Peristiwa-peristiwa itu menunjukkan hukum masih belum cukup berpihak pada anak, padahal sebagai subjek hukum, anak-anak semestinya mendapatkan perlakuan dan perlindungan yang sama dengan orang dewasa. Bahkan kalau perlu, anakpun berhak mendapatkan advokasi.

Pandangan anak dalam pengertian religius akan dibangun sesuai dengan pandangan Islam yang mempermudah untuk melaukan kajian sesuai dengan konsep-konsep Al-Qur'an dan Hadis Nabi Muhammad Saw. Islam memandang pengertian anak sebagai suatu yang mulia kedudukannya. Anak memiliki atau pendapat tempat kedudukan yang istimewa dalam nash alQur'an dan Hadits. Oleh karena itu, seorang anak dalam pengertian islam harus diperlakukan secara manusiawi dan diberikan pendidikan, pengajaran ketrampilan dari akhlakul karimah agar anak tersebut kelak akan bertanggng jawab dalam mensosialisasikan diri untuk memenuhi kebutuhan hidup dari masa depan yang kondusif. Masalah anak dalam pendapat alQur'an menjadi tanggungan kedua orang tua seperti ditegskan oleh Nabi Muhammad Saw.

Pengertian anak yang begitu sempurna dari ajaran Rasulullah, meletakkan kedudukan anak menjadi tanggungan jawab kedua orang tua. Tanggung jawab dimaksud adalah tanggung jawab syari'ah Islam yang harus diemban dalam kehidupan rumah tangga, masyarakat bangsa dan Negara sebagai suatu yang berhukum wajib. Agama Islam juga meletakkan tanggungjawab tersebut pada dua aspek, yaitu aspek duniawiah yang meliputi kesejahteraan, keselamatan didunia, dan aspek ukharawiah yang meliputi pengampunan dan pahala dari tanggung jawab dan pelaksanaannya. Aspek ukhwariah ini, meliputi pengampunan dan pahala dari penyampingan pembinaan, pemeliharaan, dan pendidikan diatas dunia.

Kedudukan anak dalam pengertian Islam, yaitu adalah titipan Allah swt. Kepada kedua orang tua, masyarakat, bangsa dan negara sebagai pewaris dari ajaran Islam (wahyu Allah swt) yang kelak akan memakmurkan dunia sebagai Rahmatanlillalamiin). Pengertian ini memberikan hak atau melahirkan hak anak yang harus diakui, diyakini, dan diamankan sebagai implementasi amalan yang diterima oleh anak dari orang tua, masyarakat, bangsa dan negara.

Menurut hukum perdata kekuasaan orang tua terhadap anak-anaknya mulai dari lahir sampai usia dewasa atau kawin. Jika sudah dewasa atau kawin, maka kekuasaannya menjadi hapus. Bisa jadi pada waktu-waktu tertentu kekuasaan itu dihapus oleh hakim dengan alasan tertentu. Kekuasaan terhadapa anak dimiliki bersama oleh suami-isteri, tetapi biasanya dipegang oleh ayah. Dalam hal-hal tertentu, seperti sakit, sedang bepergian dan sebagainya, kekuasaan itu dapat dialihkan kepada ibu. Kekuasaan itu meliputi pemeliharaan anak serta kekayannya dan mewakili anak dalam bertindak hukum kalau ia belum dianggap cakap (dibawah pengampunan)

Terkait dengan beban tanggung jawab keluarga menurut kekerabatan matrilineal, selain kedua orang tua secara hierarki, mamak juga termasuk kategori ini. Mamak termasuk orang yang berkuasa terhadap keturunan. Keturunan 
yang dimaksud adalah kemenakanya yang menjadi anak dalam keluarga inti.

Lelaki yang berasal dari luar wilayah adat Minangkabau, kemudian menyandarkan diri kapada salah satu kaum sebagai kemenakan bertali emas, lalu beranak pinak, ia tidak memikul tanggung jawab seperti mamak tersebut. Sebab, beban tanggung jawab ini terkait dengan harta pusaka tinggi. Sedangkan ia tidak mempunyai kemenakan bertali darah sebagai persyaratan pewarisan harta tersebut. Jika ia mempunyai harta pusaka tinggi (harta yang sudah diwarisi secara adat), maka ia berhak memindahtangankan atau menjualnya kepada siapa yang ia kehendaki tanpa dapat dihalangihalangi oleh kemenakannya yang bertali budi.

Bagi masyarakat Minangkabau yang menyandarkan diri kepada salah satu kaum yang bertali darah, maka ia tidak berhak mewarisi harta pusaka kaum itu. Jika diterapkan prinsip hubungan mamak-kemenakan, maka tanggungjawabanya terhadap kemenakannya sendiri menurut garis matrilineal. Izin pewarisan, hibah, pengadaian, dan sebagainya bukan kepada penghulu kaum tempat ia menyandarkan diri, tetapi kepada keluarganya secara matrilineal pula.

Jika tanggung jawab orang tua terhadap anak-anaknya sampai mereka dewasa, maka tanggung jawab dan kekuasaan mamak terhadap kemenakan seakan-akan bukan dalam waktu terbatas. Kekuasaan itu mulai terlihat sejak kemenakan masih kecil, mencarikan jodoh, sampai berumah tangga. Biaya untuk kelangsungan hidup rumah tangganya yang ditanggung oleh mamak yang diambilkan dari penghasilan harta pusaka tinggi kendati suaminya berkecukupan atau tidak.

Bagi harta pusaka yang telah dibagi-bagi (gadang manyimpang), sesuai dengan pemekaran suku dan penghulu, maka kekuasaan mamak terhadap kemenakan juga menjadi terbatas hanya terhadap kemenakan dalam anggota kaumnya yang telah dibagi-bagi itu. Kekuasaan tersebut tidak bisa diterapkan atau dipaksakan terhadapkemenakan bertali adat, bertali budi, atau bertali emas. Sebab kemenakan dalam bentuk ini bukan sebagai pewaris harta pusaka kaum itu dan bukan pula dibesarkan dari harta pusaka kaum tersebut.

Posisi kekuasaan mamak yang besar ini berdampak kepada mengecilnya kekuasaan ayah terhadap anak. Terkait dengan sistem perkawinan consanguinal, maka mamak menjadi sangat menentukan. Karena itu di Minangkabau sejak sebelum islam sampai kepada masa perangkulan adat dan Islam, perjodohan berjalan ibarat kisah dongeng Siti Nurbaya.Pihak perempuan atau laki-laki tidak perlu tahu seluk beluk calonnya. Mereka menunggu "bahan jadi" atau perhitungan matang antar kedua belah keluarga. Pertemuan awal mereka hanya bermula pada malam penganten saja. Ketika akad nikah, yang hadir di depan penghulu hanya calon suami yang akan menerima akad dan wali dari calon isteri. Jika walinya ayah, maka ia pun hanya menerima perhitungan matang, dari kaum anaknya. Wewenangnya hanya ketika akad berlangsung. Selebihnya, baik sebelum maupun sesudah akad nikah, mamak mengambil peran.

\section{Metode}

Penelitian ini menggunakan penelitian deskriptif yang bertujuan agar dapat menggambarkan berbagai fenomena realitas sebenarnya yang menjadi obyek penelitian agar lebih mendalam dan memperoleh data yang diinginkan dengan melihat dan mempelajari peelindungan anak dari perspektif hokum Islam dan undang-undang. 


\section{Hasil dan Pembahasan}

Anak adalah amanah sekaligus karunia Tuhan Yang Maha Esa, yang senantiasa harus kita jaga karena dalam drinya melekat harkat, martabat dan hak-hak sebagai manusia yang harus dijunjung tinggi. Hak Asasi Manusia merupakan bagian dari hak asasi manusia yang termuat dalam Undang-Undang Dasar 1945 dan Konvensi Perserikatan Bangsa-bangsa tentang Hak-Hak Anak.

a) Ketentuan Umum Pasal I: Dalam Peraturan Pemerintah ini yang dimaksud dengan : Anak angkat adalah anak yang haknya dialihkan dari lingkungan kekuasaan keluarga orang tua, wali yang sah, atau orang lain yang bertanggung jawab atas perawatan pendidikan, dan membesarkan anak tersebut, ke dalam lingkungan keluarga orang tua angkatnya berdasarkan keputusan atau penetapan pengadilan.

b) Pengangkatan anak adalah suatu perbuatan hukum yang mengalihkan seorang anak dari lingkungan kekuasaan orang tua, wali yang sah, atau orang lain yang bertanggung jawab atas perawatan, pendidikan dan membesarkan anak tersebut, ke dalam lingkungan keluarga orang tua angkat.

c) Orang tua adalah ayah dan/atau ibu kandung, atau ayah dan/atau ibu tiri, atau ayah dan/atau ibu angkat.

d) Orang tua angkat adalah orang yang diberi kekuasaan untuk merawat, mendidik, dan membesarkan anak berdasarkan peraturan perundang-undangan dan adat kebiasaan.

e) Lembaga pengasuhan anak adalah lembaga atau organisasi sosial atau yayasan yang berbadan hukum yang menyelenggarakan pengasuhan anak terlantar dan telah mendapat izin dari Menteri untuk melaksanakan proses pengangkatan anak. f) Masyarakat adalah perseorangan, keluarga, kelompok dan organisasi sosial dan/atau organisasi kemasyarakatan.

g) Pekerja sosial adalah pegawai negeri sipil atau orang yang ditunjuk oleh lembaga pengasuhan yang memiliki kompetensi pekerjaan sosial dalam pengangkatan anak.

h) Instansi sosial adalah instansi yang tugasnya mencakup bidang sosial baik dipusat maupun di daerah.

i) Menteri adalah menteri yang menyelenggarakan urusan pemerintahan dibidang social (Peraturan Pemerintah: Pengangkatan Anak (PP RI Nomor 54 Tahun 2007)).

Pasal 12: (1) Syarat anak yang akan di angkat, meliputi:

a) belum berusia 18 (delapan belas) tahun

b) merupakan anak terlantar atau ditelantarkan;

c) berada dalam asuhan keluarga atau dalam lembaga pengasuhan anak dan;

d) memerlukan perlindungan khusus.

(2) Usia anak angkat sebagaimana dimaksud pada ayat (1) huruf a meliputi:

a) anak belum berusia 6 (enam) tahun, merupakan prioritas utama

b) anak berusia 6 (enam) tahun sampai dengan belum berusia 12 (dua belas) tahun, sepanjang adab alasan mendesak; dan

c) anak berusia 12 (dua belas) tahun sampai dengan belum berusia 18 (delapan belas) tahun, sepanjang anak memerlukan perlindungan khusus.

Pasal 13 Calon orang tua angkat harus memenuhi syarat-syarat:

a) sehat jasmani dan rohani; 
b) berumur paling rendah 30 (tiga puluh) tahun dan paling tinggi 55 (lima puluh lima) tahun

c) beragama sama dengan agama calon anak angkat

d) berkelakuan baik dan tidak pernah dihukum karena melakukan tindak kejahatan

e) berstatus menikah paling singkat 5 (lima) tahun

f) tidak merupakan pasangan sejenis

g) tidak atau belum mempunyai anak atau hanya memiliki satu orang anak

h) dalam keadaan mampu ekonomi dan sosial

i) memperoleh persetujuan anak dan izin tertulis orang tua atau wali anak

j) membuat pernyataan tertulis bahwa pengangkatan anak adalah demi kepentingan terbaik bagi anak kesejahteraan dan perlindungan anak.

k) Adanya laporan sosial dari pekerja sosial setempat

1) Telah mengasuh calon anak angkat paling singkat 6 (enam) bulan, sejak izin pengasuhan diberikan; dan

m) Memperoleh izin Menteri dan/ atau kepala instansi social (Peraturan Pemerintah: Pengangkatan Anak (PP RI Nomor 54 Tahun 2007)).

Pasal 26: Bimbingan terhadap pelaksanaan pengangkatan anak dilakukan oleh Pemerintah danmasyarakat melalui kegiatan:
a) Penyuluhan;
b) Konsultasi;
c) Konseling;
d) Pendampingan; dan
e) Pelatihan.

Pasal 27: (1) Penyuluhan sebagaimana dimaksud dalam Pasal 26 huruf a dimaksudkan agar masyarakat mendapatkan informasi dan memahami tentang persyaratan, prosedur dan tata cara pelaksanaan pengangkatan anak. (2) Penyuluhan sebagaimana dimaksud pada ayat (1) bertujuan untuk;

a) Meningkatkan pemahaman tentang pengangkatan anak

b) Menyadari akibat dari pengangkatan anak; dan

c) Terlaksananya pengangkatan anak sesuai dengan peraturan perundang-undangan.

Pasal 28; (1) Konsultasi sebagaimana dimaksud dalam Pasal 26 huruf b, dimaksudkan untuk membimbing dan mempersiapkan orang tua kandung dan calon orang tua angkat atau pihak lainnya agar mempunyai kesiapan dalam pelaksanaan pengangkatan anak. Konsultasisebagaimana dimaksud pada ayat (1) bertujuan untuk:

a) Memberikan informasi tentang pengangkatan anak; dan

b) Memberikan motivasi untuk mengangkat

Pasal 29; (1) Konseling sebagaimana dimaksud dalam pasal 26 huruf c, dimaksudkan untuk membantu mengatasi masalah dalam pengangkatan anak. (2) Konseling sebagaimana dimaksud pada ayat (1) bertujuan untuk:

a) Membantu memahami permasalahan pengangkat anak; dan

b) Memberikan alternatif pemecahan masalah pengangkatan anak.

Pasal 30; (1) Pendampingan sebagaimana dimaksud dalam pasal 26 huruf d dimaksudkan untuk membantu kelancaran pelaksanaan pengangkatan anak. (2) Pendampingan sebagaimana dimaksud pada ayat (1) bertujuan untuk: 
a) Meneliti dan menganalisis permohonan pengangkatan anak; dan

b) Membantu perkembangan anak dalam pengasuhan orang tua angkat

Pasal 34 Pengawasan dilaksanakan terhadap :
a) Orang perseorangan
b) Lembaga pengasuhan
c) Rumah sakit bersalin
d) Praktek-praktek kebidanan; dan
e) Panti sosial pengasuhan anak.

Pasal 35 Pengawasan terhadap pelaksanaan pengangkatan anak dilakukan oleh Pemerintah dan masyarakat

Pasal 36 Pengawasan oleh Pemerintah sebagaimana dimaksud dalam pasal 35 dilakukan oleh Departemen Sosial

Pasal 37 Pengawasan oleh masyarakat sebagaimana dimaksud dalam pasal 35 dilakukan antara lain oleh:
a) Orang perseorangan
b) Keluarga;
c) Kelompok;
d) Lembaga pengasuhan anak; dan
e) Lembaga perlindungan anak.

Pasal 38; (1) Dalam hal terjadi atau diduga terjadi penyimpangan atau pelanggaran terhadap pelaksanaan pengangkatan anak, masyarakat dapat melakukan pengaduan kepada aparat penegak hukum dan/atau Komisi Perlindungan Anak Indonesia, Instansi sosialsetempat atau Menteri.(2) Pengaduan diajukan secara tertulis disertai dengan identitas diri pengadu dan data awal tentang adanya dugaan penyimpangan atau pelanggaran.

Anak merupakan bagian dari generasi muda, penerus cita-cita perjuangan bangsa dan sumber daya manusia bagi pembangunan nasional. Untuk mewujudkan sumber daya manusia Indonesia yang berkualitas diperlukan pembinaan sejak dini yang berlangsung secara terus menerus demi kelangsungan hidup pertumbuhan dan perkembangan fisik, mental dan sosial anak (Setyowati Irma, 1990: 40).

Kondisi ekonomi nasional yang kurang mendukung sangat mempengaruhi kondisi perekonomian keluarga dan berdampak pada tingkat kesejahteraan anak Indonesia. Kenyataan yang kita jumpai sehari-hari didalam masyarakat masih banyak dijumpai anak-anak yang hidup dalam kondisi yang tidak menguntungkan, dimana banyak ditemui anak jalanan, anak terlantar, yatim piatu dan anak penyandang cacat dengan berbagai permasalahan mereka yang kompleks yang memerlukan penanganan, pembinaan dan perlindungan, baik dari pihak Pemerintah maupun masyarakat.

Komitmen Pemerintah untuk memberikan perlindungan terhadap anak telah ditindak lanjuti dengan disahkannya Undangundang Nomor 23 Tahun 2002 tentang Perlindungan Anak.Undang-undang ini mengatur tentang berbagai upaya yang dilakukan dalam rangka perlindungan, pemenuhan hakhak dan peningkatan kesejahteraan anak.Salah satu solusi untuk menangani permasalahan anak dimaksud yaitu dengan memberi kesempatan bagi orang tua yang mampu untuk melaksanakan pengangkatan anak.Tujuan pengangkatan anak hanya dapat dilakukan bagi kepentingan terbaik anak dan harus berdasarkan pada peraturan perundang-undangan yang berlku dan/atau berdasarkan pada kebiasaan setempat.

Mengingat banyaknya penyimpangan yang terjadi dalam masyarakat atas pelaksanaan pengangkatan anak yaitu pengangkatan anak dilakukan tanpa melalui prosedur yang benar, pemalsuan data, perdagangan anak bahkan telah terjadi jual beli organ tubuh anak. Untuk itu, 
perlu pengaturan tentang pelaksaaan pengangkatan anak, baik dilakukan oleh Pemerintah maupun oleh masyarakat, yang dituangkan dalam bentuk Peraturan Pemerintah (Kansil, C.S.T., 1986: 29).

Peraturan Pemerintah ini dapat dijadikan pedoman dalam pelaksanaan pengangkatan anak yang mencakup ketentuan umum, jenis pengangkatan anak, syarat-syarat pengangkatan anak, tata cara pengangkatan anak, bimbingan dalam pelaksanaan pengangkatan anak, pengawasan pelaksanaan pengangkatan anak dan pelaporan. Dengan berlakunya Peraturan Pemerintah ini juga dimaksudkan agar pengangkatan anak dilaksanakan sesuai dengan ketentuan peraturan perundang-undangan sehingga dapat mencegah terjadinya penyimpangan pada akhirnya dapat melindungi dan meningkatkan kesejahteraaan anak demi masa depan dan kepentingan terbaik bagi anak.

Secara sederhana, anak yang telah tidak melaksanakan apa yang disebutkan dalam AlQur'an, dapat dikatakan sebagai anak nakal. Tentunya dengan kadar yang berbeda untuk masing-masingnya. Akibat perilaku anak yang nakal, jelas akan memberikan efek yang kurang menguntungkan, baik bagi dirinya dan juga lingkungannya. Bahkan lebih dari itu,apabila perbuatannya telah mencocoki apa yang disebutkan di dalam Undang-undang, maka anak yang bersangkutan akan berhadapan dengan hukum dan diproses secara hukum (Maulana Hasan Wadong, 2000:61). Undangundang No.3 Tahun 1997 tentang Peradilan anak telah memberikan penegasan dan pengaturan tentang proses hukum yang mesti dijalankan terhadap seorang anak yang melakukan tindak pidana. Penegasan dan pengaturan tersebut adalah sebagai berikut:

Seorang anak yang melakukan tindak pidana dapat diajukan ke Pengadilan anak, apabila ia berusia antara 8 tahun dan belum berusia 18 tahun serta belum kawin.
1) Seorang anak yang berumur antara 8 tahun dan belum berusia 18 tahun melakukan tindak pidana, sementara ia baru diajukan kePengadilan setelah berusia 18 tahun, maka ia tetap diajukan ke Pengadilan anak, sepanjang anak tersebut belum berusia 21 tahun.

2) Terhadap seorang anak yang melakukan tindak pidana dan belum berusia 8 Tahun, dapat saja dilakukan penyidikan dengan memperhatikan hal-hal: a). jika hasil penyidikan menunjukkan bahwa anak tersebut diserahkan kepada orang tuanya, walinya atau orang tua asuhnya; b). Jika penyidikan menunjukkan bahwa anak tersebut tidak mungkin di bina, maka anak tersebut diserahkan kepada lembaga sosial yang dikelola oleh Pemerintah setelah mendengar pertimbangan dari Pembimbing Kemasyarakatan.

3) Anak yang melakukan tindak pidana secara bersama-sama dengan orang dewasa atau anggota TNI atau Polri, maka masingmasing proses persidangannya diserahkan kepada yang berhak.

4) Hakim, Penuntut Umum. Penyidik dan Penasehat Hukum serta petugas lainnya dalam sidang tidak menggunakan toga.

5) Sidang Pengadilan anak dilakukan secara tertutup dan hanya boleh dihadiri oleh anak yang bersangkutan, orang tuanya atau walinya atau orang tua asuhnya, penasehat hukum dan pembimbing kemasyarakatan atau pihak lain yang diijinkan oleh Hakim, akan tetapi putusannya diucapkan terbuka untuk umum.;

6) Sebelum sidang dimulai, Hakim memerintahkan kepada Pembimbing Kemasyarakatan untuk menyampaikan laporan hasil penelitian kemasyarakatan mengenai anak yang bersangkutan. Laporan yang dimaksud meliputi data anak, 
keluarga, pendidikan, kehidupan sosial anak dan kesimpulan.

7) Sebelum hakim memberikan putusannya, ia harus memberi kesempatan kepada orang tua atau walinya atau pengasuhnya untuk mengemukakan sagala sesuatu yang bermanfaat bagi anak yang dimaksud.

8) Putusan yang dijatuhkan oleh hakim wajib mempertimbangkan laporan penelitian kemasyarakatan dari pembimbing

9) Pidana yang dijatuhkan kepada anak dapat berupa pidana penjara, kurungan, pengawasan atau pidana tambahan berupa pembayaran ganti rugi;

10) Pidana penjara yang dijatuhkan kepada anak adalah $1 / 2$ dari pidana pokok yang dijatuhkan kepada orang yang dewasa. Jika pidana itu berupa pidana mati atau seumur hidup, maka yang dijatuhkan terhadap anak adalah pidana 10 tahun.

11) Jika seorang anak melakukan tindak pidana dan berumur belum 12 tahun, sementara ancaman hukumannya adalah pidana mati atau penjara seumur hidup, maka bagi anak dijatuhkan hukuman : a. dikembalikan kepada orang tua; atau walinya, atau orang tua asuh dari anak tersebut ; b. anak tersebut diserahkan kepada negara untuk mengikuti Pendidikan dan pembinaan atau latihan kerja ; c. menyerahkan anak ke lembaga sosial yang dikelola oleh Pemerintah atau organisasi kemasyarakatan yang bergerak dalam bidang pendidikan, pembinaan dan latihan kerja.

12) Hukuman kurungan bagi anak adalah $1 / 2$ dari orang dewasa ;

13) Pidana denda yang dijatuhkan kepada anak adalah $1 / 2$ dari orang dewasa. Jika denda tidak dibayar, diganti dengan denda yang berlangsung paling lama 90 hari
14) Pidana perampasan barang-barang tertentu hanya terbatas barang hasil tindak pidana dan yang digunakan untuk melakukan tindak pidana

15) Pidana pembayaran ganti rugi dibebankan kepada orang tuanya atau pihak lain yang menjalankan kekuasaan atas orang tua

16) Pidana bersyarat bagi anak, hanya dapat dijatuhkan jika ia dijatuhi pidana maksimum 2 tahun

17) Pidana pengawasan dalam batas waktu minimal 3 bulan dan maksimal 2 tahun. Pidana pengawasan adalah pidana yang khusus dikenakan kepada anak, yakni pengawasan yang dilakukan oleh Jaksa terhadap perilaku anak dalam kehidupannya sehari-hari di rumah dan pemberian bimbingan yang diajukan oleh pembimbing kemasyarakatan(Waluyadi, 2009:69).

Hal-hal sebagaimana tersebut diatas, akan diberlakukan terhadap anak-anak kita apabila oleh undang-undang disebut sebagai anak nakal. Semua dari kita tentunya tidak mengharapkan "predikat dan status" yang demikian. Oleh karena, meskipun hal yang dikedepankan terhadap penjatuhan terhadap anak adalah bersifat pembinaan dan kebijaksanaan, akan tetapi pendekatan yang digunakan adalah pendekatan yuridis.

\section{Simpulan}

Sebijak apapun sebuah kebijakan yuridis, tidak selalu harus berbarengan dan berakhir dengan sebuah kebijaksanaan.Oleh karena apabila yang demikian itu dilakukan,maka yang terjadi adalah pelanggaran hukum.Satu-satunya jalan yang harus dilakukan adalah sebagai orang tua kita harus menempatkan anak sebagai amanat (Husen Abd.Rozak, 1992:73). Menyianyiakan amanat adalah khianat dan khianat adalah perbuatan dosa. Penulis berkeyakinan, 
apabila orang tua telah menjalankan apa yang di isyaratkan oleh Allah sebagaimana tersebut diatas dalam Al-Qur'an, Al-Luqman 1-13 dengan baik dan penuh tanggung jawab, maka apa yang disebut dengan anak nakal atau predikat yang sejenis dengan itu dapat diminimalisir. Akan tetapi, jika para orang tua melakukan hal yang sebaliknya, maka tunggu saat nanti, seorang anak hanya akan mengantar kepada kita, jurang kesengsaraan, baikdi dunia dan diakhirat.

Jangan percayakan anak-anak kita terhadap media apapun bentuknya tanpa kontrol. Jadilah kita sebagai pendidik yang pertama dan utama. Telah banyak anak yang seronok perkataannya, kasar perangainya, tidak dapat menghormati terhadap orang tua, tidak sayang terhadap yang sebaya dan yang lebih muda, atau perilaku yang berdasarkan naluri, kita tidak menyetujuinya.

Jika hal tersebut diatas benar-benar terjadi, tidak ada kata terlambat. Lakukan sesuatu dan jangan menunggu waktu. Kembalikan proses pembinaan dan pendidikan anak-anak kita sebagaimana yang diajarkan oleh agama. Tentunnya, kesemuanya itu baru dapat kita terapkan, apabila kita telah melaksanakan. Sebab, anak akan mengikuti apa yang kita kerjakan dan bukan apa yang kita katakan.

\section{Daftar Pustaka}

Irma, Setyowati, 1990, Aspek Hukum Perlindungan Anak, Penerbit Bumi Aksara, Jakarta.

Kansil, C.S.T., 1986, Pengantar Ilmu Hukum Dan Tata Hukum Indonesia, Penerbit Balai Pustaka, Jakarta.

Wadong, Maulana Hasan, 2000, Pengantar Advokasi Dan Hukum Perlindungan Anak, Penerbit PT.Gramedia Widiasarana Indonesia, Jakarta.

Waluyadi, 2009, Hukum Perlindungan Anak, Anggota IKAPI No.043/JBA/92, CV. Mandar Maju.

Rozak, Husen Abd., 1992, Hak-hak Anak Dalam Islam, Penerbit Fikahati, Aneska, Jakarta.

Peraturan Pemerintah Pengangkatan Anak (PP RI nomor 54 Tahun 2007).

Perlindungan Anak (Undang-undang RI nomor 23 tahun 2002).

Pengadilan Anak (Undang-undang RI Nomor 3 Tahun 1997).

Kesejahteraan Anak (Undang-undang RI Nomor 4 Tahun 1979).

Perkawinan (Undang-undang No.1 Tahun 1974). 